\title{
Chapter 13. The Politics of Marriage and the Marriage of Polities in Gowa, South Sula Wesi, During the 16th and 17th Centuries
}

\section{F. David Bulbeck}

\section{The Wider Background}

The traditional political systems of the Malay and Bugis worlds, northern Sumatra and Java, produced a high frequency of female rulers by world standards (Reid 1988:169-172). Nonetheless the élite titles in these systems still tended to be inherited patrilineally even though very different descent principles, usually bilateral but even matrilineal, operated within society as a whole (e.g. Gullick 1958; Palmier 1969; de Josselin de Jong 1980:10; Millar 1989:25). Fox observes that élite patrilinealism within a bilateral system is only one variant, albeit the most common, of a widespread tendency for Austronesian élites to claim a separate origin from commoners and follow a distinct and socially exclusive descent system. These devices allow the élite to maintain precedence over restricted resources, and characterize societies which have undergone consolidation after an earlier phase of lateral expansion (Fox 1995). Moreover, as this paper will show in the case of the Makassar state of Gowa, the élite were further advantaged by a selective adoption of the kinship system prevalent in society as a whole. So even though the highest Makassar posts were held almost exclusively by patrilineal descendants, bilateral kinship principles (notably the real or symbolic transfer of authority through related women) underpinned the central position of the highest status individuals within society, and guaranteed the resilience of the system as a political entity.

As recorded ethnographically the Makassar and the Bugis, South Sulawesi's two main ethnic groups, share a very similar social organization. Both are organized into overlapping sets of bilateral kindreds rather than sharply demarcated descent groups. Individuals can choose their particular affiliation, resulting in the crystallization of discrete networks of (usually) related individuals. Postmarital residence can be either virilocal or (more usually) uxorilocal, the spouses retain membership within their natal group, and the children enjoy homologous relationships with the families of both parents. While the flexibility allows the ready incorporation of newcomers, the communities maintain their stability through physical and occupational propinquity and some measure of endogamy. An individual's behaviour is also strongly 
constrained by his or her status which is largely ascriptive, especially for women who, in the rôle of (principal) wife, mark the status attained by the more socially mobile men (Chabot 1950; Millar 1989; Acciaioli 1989).

The ascription of status is best described with reference to traditional, pre-twentieth century Bugis-Makassar society, since some of the social divisions have been formally abolished even if the effects still persist in more conservative areas (Röttger-Rössler 1989:28 ff.). Society was traditionally stratified into aristocrats, commoners and slaves. The aristocracy and its various ranks consisted of those who could trace their origins to the supposed founders of the Bugis-Makassar kingdoms, the white-blooded Tomanurung. In theory aristocrats were ranked by the degree to which their white blood, as traced through both parents, remained undiluted by the red blood of commoners; access to titles depended on nobility of birth, and only pure descendants reserved the right to rule a kingdom (Friedericy 1933; Mukhlis 1975; Acciaioli 1989). Despite the essentially bilateral manner of ascribing status, a patrilateral bias clearly existed, at least among the Makassar (Röttger-Rössler 1989:42-43; Mukhlis 1975:37-38).

Now, bilateral descent principles can readily generate a nobility through marriages between royalty and commoners, but clearly the origins of the white-blooded royalty must stand outside the bilateral network - hence Tomanurung, the descended one(s). In some cases this external derivation indeed occurred, as for example recorded with the Konjo Makassar living at Kasepekang in the Gowa highlands. In the late nineteenth century a lowland Gowa aristocrat called Daeng Bunding married into the Kasepekang nobility and was installed as Karaeng. The Kasepekang Karaeng and other prominent nobles now trace a real or fictional genealogical closeness to Daeng Bunding through his three official wives (Röttger-Rössler 1989:38-40). The observation by Rössler (1987:66), that the Kasepekang Karaeng descent group traces itself to a heavenly princess comparable to the Tomanurung who supposedly began the Gowa royal line, presumably hinges on this Daeng Bunding.

Moreover, the existence of pure white-blooded royals presupposes either a quantity of original Tomanurung amounting to a breeding population or massive inbreeding within the royalty. But neither was true of the Makassar rulers who instead clearly referred to their patriline as the critical pedigree defining purity of descent. The relevant ethnographic analogy comes from the Kasepekang Konjo whose élite regulate their membership through bilateral descent groups (pattola) consisting of the descendants of the ancestral holder of a hereditary title. Theoretically eligible candidates for the title, in practice men, are individuals either belonging to the pattola or married to a woman within the pattola. However, at any point in time, the core of the pattola lodges with the title holder and his sons (Rössler 1987:64-66). The prerogative of the noblest Kasepekang Konjo, to apply the strictest criteria for admission into the pure nobility 
(Röttger-Rössler 1989:43), combined with the patrilateral bias in the ascription of status, would appear to legitimize the usual patrilineal succession of noble titles.

Nonetheless the principle of bilateral descent is an equally intrinsic part of the Kasepekang system. It provides the flexibility which has allowed occasional lateral movements of titles in response to political machinations and individual aptitudes. We have already mentioned the case of Daeng Bunding who, as a prominent outsider, cemented his central position by marrying widely into the Kasepekang nobility (Röttger-Rössler 1989). The bilateral ideology also encourages potential title holders to strengthen their eligibility by marrying women close to the core, generating the endogamy towards the core which maintains the distinctiveness of the lineage. Marriages between equals belonging to different pattola are also sanctioned, reinforcing the social distance between nobles and commoners, and the attachments of the lesser pattola to the central pattola associated with the highest title of Karaeng. Last but not least the bilateral ideology retards the fissioning of descent groups so that the nobility in general, and each pattola according to its prestige, hold a central position within the social network (Rössler 1987:66-67).

Gullick (1958) documented a similar organization on a larger scale for the Malay peninsula states, leading him to coin the description "status lineages" in contradistinction to the classical patrilineal "segmentary lineages" of the Nuer. As Fox (1971) demonstrates for the Rotinese, a patrilineal society combining deep genealogical knowledge among the nobility and "genealogical amnesia" among the commoners can also generate status lineages which place individuals within an overarching social hierarchy. Fox (1995) generalizes further by noting that Austronesian societies ruled by a high élite typically present "apical demotion systems". These systems continually reassess the comparative status of lines and their members depending on which line, and ultimately which member, holds the most prestigious title. This individual represents the apical point against which other lines (and their members) automatically lose status unless they can curtail their genealogical distance (Fox 1995). In the Kasepekang system, patrilineal descent acts as the usual criterion for succession to the apex, while bilateral descent both holds the other lines to the apex and allows movement towards (or even usurpation of) the apical point.

The present paper summarizes my analysis (Bulbeck 1992) of the Makassar texts, covering the sixteenth and seventeenth centuries, which describe the rise and fall of the Gowa empire. The analysis shows that Gowa's sociopolitical organization was elaborated on the basic principles described for the Kasepekang Konjo. The elaborations concern Gowa's annexation of previously autonomous territories, the development of an overarching hierarchy incorporating sets of titles of distinct origins, and the creation of a high royalty both distinct from 
but binding the lesser social echelons. All in all, expanding political power was associated with the ability to attract well-born brides, absorb previously independent titles and assure patrilineal succession of the lineage's own titles, while decreasing political power was associated with the reverse. Furthermore the system showed a remarkable ability to legitimize political change.

\section{Background to Gowa}

The people generically called the Makassar occupy the far south of South Sulawesi (Sulawesi's southwest peninsula). They speak three related languages - Konjo and Selayar in the east, and Makassar proper in the west (Grimes and Grimes 1987). The lowlands support generally denser populations than those found in the Bugis heartland to the immediate north, even though the latter region contains South Sulawesi's most extensive wet rice lands. Indeed, South Sulawesi's southwest corner between Gowa and Sanrabone (see Map 1) holds rural population densities comparable to those in Java and Bali. The coastal strip, rich in maritime and littoral resources, backs against extensive alluvial plains which are ideal for sawah. Irrigation schemes first developed by the Dutch permit double cropping and hence higher populations in favoured areas. Nonetheless the traditional annual sawah cultivation, based on the very pronounced monsoon, also supported hundreds of thousands of people by the seventeenth century, with densities apparently reaching towards 1000 people per square kilometre (Bulbeck 1992).

Two major trade routes from Java lay along the south coast by at least the fourteenth century. One route extended via Selayar to the spice islands, and the other extended to Luwuk with its nickeliferous iron and other valuable primary produce (Caldwell 1988). Selayer, Luwuk, plus Bantaeng and Makassar along the south coast, are the only identifiable South Sulawesi toponyms mentioned in the Majapahit literature. Selayer, Luwuk and the south coast are also the parts of South Sulawesi evincing the strongest Javanese influence (Reid 1983; Bulbeck 1992). The origins of the Bugis king dom of Luwuk specifically invoke Majapahit (Caldwell 1988), while the founder of the Makassar kingdom of Sanrabone was reportedly an immigrant from north Majapahit (Bulbeck 1992).

The Bugis agrarian kingdoms show the reverse constellation of traits absence from the Majapahit literature, little direct Javanese influence, and Tomanurung with explicitly local, Bugis origins. However, far from having been a cultural backwater, by c. 1400 AD this area had apparently developed the first South Sulawesi scripts. The resulting texts show that the Bugis heartland supported the largest fourteenth-century kingdoms in South Sulawesi, and probably the oldest kingdoms as well (original study by Caldwell [1988] as interpreted by Bulbeck [1992]). 


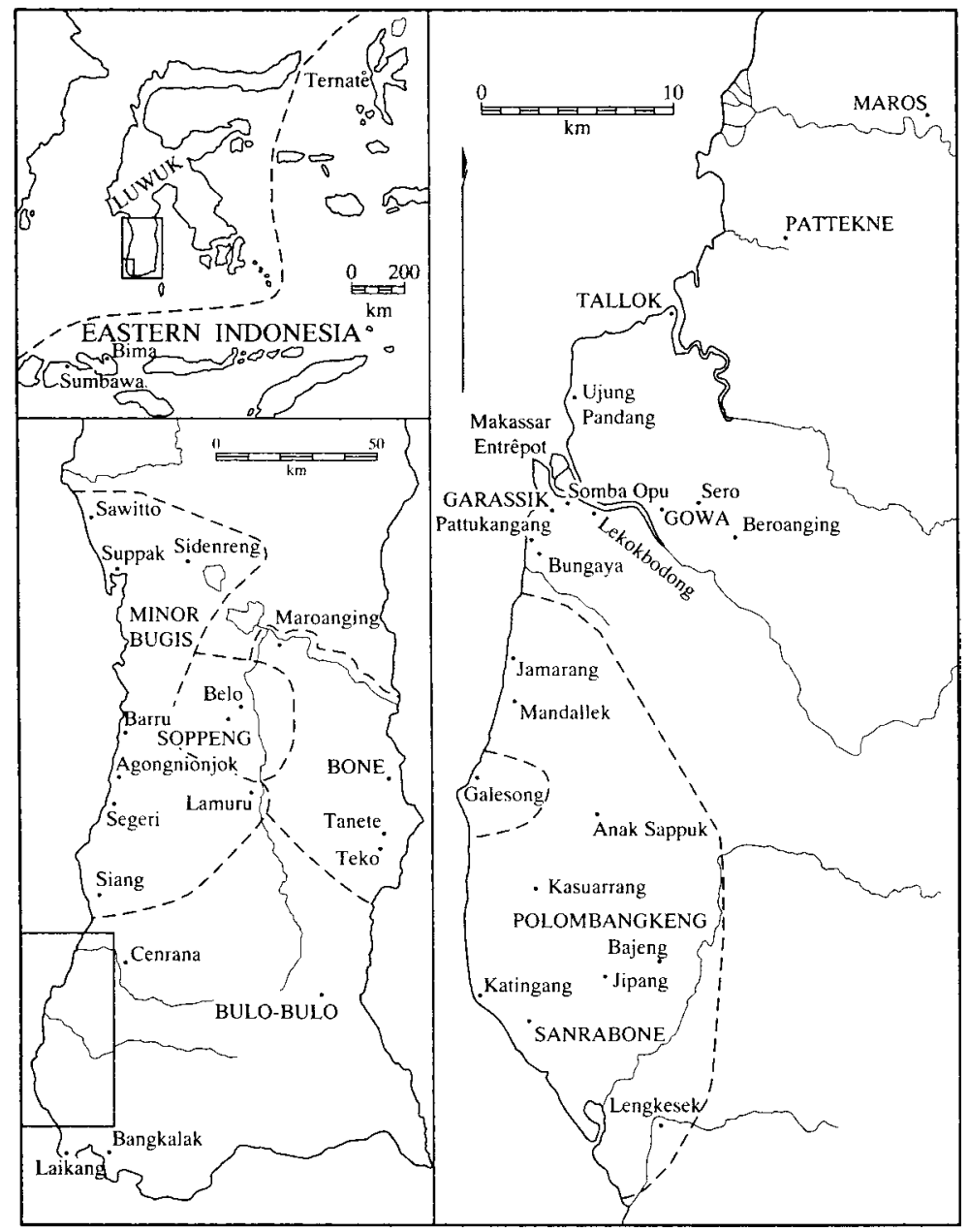

\section{Map 1. "Lineage groups" (capitalized) and other key places.}

Granted the general dichotomy between maritime kingdoms with their external orientation and occasional claims to foreign origins, and the locally oriented agrarian kingdoms, Gowa combines the two. Gowa's origins are ascribed to the marriage between a mortal called Karaeng Bayo or the "Bajau King", and a heavenly nymph who descended on a hill within Gowa's rice fields (Reid 1983). Although dressed up as legend the origin story appears to reflect a real historical memory, to judge from the concordance between the archaeological and genealogical data. At c. 1300 AD a Bajau chief, based at the river mouth port which later became Sanrabone, apparently married a Katangka (pre-Gowa) princess of Makassar ethnicity to give rise to Gowa's royal line (Bulbeck 1992).

By around 1500, when a detailed picture emerges of South Sulawesi's southwest corner (see Map 1), the near-coastal agrarian kingdoms dominated 
the small trading communities based at the river mouths. For instance, after a succession dispute within Gowa the defeated faction moved to the mouth of the Tallok River, overpowered the local inhabitants and established the kingdom of Tallok. In the same vein Gowa, Tallok and Siang successively conquered Garassik, then a small port-polity named after Gresik (north Java) but containing a significant Bajau component. After finally wrestling back Garassik by the 1540s, Gowa developed its demographic and geographical advantages to dominate South Sulawesi's long distance trade. In a series of sweeping military campaigns, Gowa raided other polities throughout the peninsula, and directly conquered the kingdoms from Maros in the north to Bajeng and Katingang in the south (Bulbeck 1992).

In 1593 Tallok instigated a palace revolution whereby the area conquered by Gowa now supported a confederation of powerful status lineages. While the Gowa royalty formally headed the larger political umbrella, which I call "greater Gowa", leadership often resided with Tallok. For instance it was the Tallok raja who adopted Islam in 1605 and established political hegemony throughout the South Sulawesi peninsula under the banner of Islam. The individual in question, Sultan Abdullah, also developed the entrepôt of Makassar to the point where greater Gowa rivalled the Dutch East India Company (VOC) for control over the Moluccan spice trade (Andaya 1981). Makassar grew so large during the mid-seventeenth century that its population can be estimated at 100,000 inhabitants, and its status as a major rice exporter during the early seventeenth century changed to one of major rice importer (Reid 1987). 


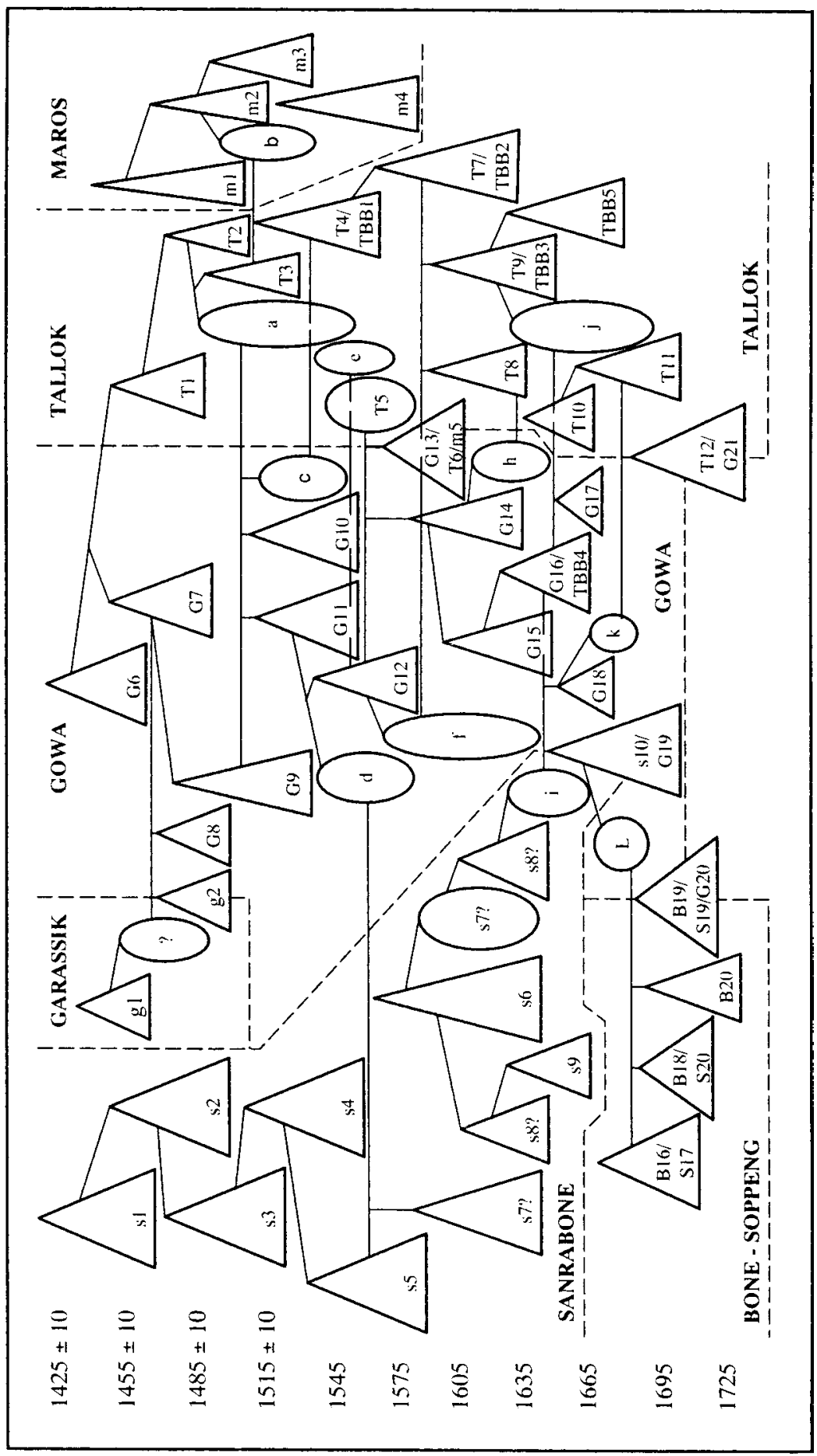

Figure 1. Skeletal genealogical outline of royal Makassar history. 


\section{SANRABONE:}

s1 = Karaeng Pancabelong; s2 = Tunijallok ri Pakrasana; s3 = Karaeng Massewaya; s4 = Tonibasara; s5 = Tumenanga ri Parallekkena; s6 = Tumenanga ri Campagana; s7?(left) = Karaeng Bambanga; s7?(right) = Karaenga I Pucu; s8?(left) = Tumenanga ri Buttana; s8?(right) = Karaeng Banyuanyarak; s9 = Puanna Jenalak; i = Petak Daeng Nisali.

BONE-SOPPENG:

B16/S17 = Alimuddin; B18/S20 = Sulaiman; B20 = Abdullah Mansyur; B19/S19/G20 = Ismail.

GARRASIK:

gl = Somba Garassik.

\section{GOWA:}

G6 = Tunatangkaklopi; G7 = Batara Gowa; G8 = Tunijallok ri Passukik; g2 = Karaeng Barataua Karaeng Garassik; G9 = Tumapakrisik Kallona; G10 = Tunipalangga; c = Karaenga Somba Opu; G11 = Tunibatta; G12 = Tunijallok; $\mathrm{d}=$ Karaeng Mapekdaka; $\mathrm{f}=$ Tuniawanga ri Kalassakanna; G13/T6/m5 = Tunipasuluk; G14 = Alauddin; G15 = Malikussaid; G16/TBB4 = Hasanuddin; G17 = Amir Hamzah; G18 = Muhammad Ali; s10/G19 = Abdul Jalil; $\mathrm{k}=$ Karaeng Parang-Parang; 1 = Karaeng Pattukangang.

\section{TALLOK:}

$\mathrm{T} 1$ = Karaengloe di Sero; $\mathrm{T} 2$ = Tunilabu di Suriwa; T3 = Tunipasuru; $\mathrm{a}$ = Karaengloe Bainea; $\mathrm{T} 4 / \mathrm{TBB} 1$ = Tumenanga ri Makkoayang; $\mathrm{T} 5=$ Karaeng Bainea; e = Karaeng Batu-Batu; T7/TBB2 = Abdullah; $\mathrm{T} 8=$ Mudhaffar; T9/TBB3 = Mahmud; TBB5 = Karaeng Karunrung; j = Raja Perempuan; $\mathrm{T} 10=$ Harrunarasyid; $\mathrm{T} 11=$ Abdul Kadir; $\mathrm{T} 12 / \mathrm{G} 21=$ Sirajuddin.

MAROS:

$\mathrm{m} 1$ = Karaengloe ri Pakerek; m2 = Karaeng Loeya; m3 = Tuamenanga ri Bulukduaya; $\mathrm{b}=$ Tumamaliang ri Tallok; $\mathrm{m} 4=$ Tunikakassang.

\section{Legend to Figure 1}


In 1667 the Bone noble Arung Palakka (later Sultan Sahaduddin) and his Bone and Soppeng Bugis rebels joined forces with the VOC and defeated greater Gowa during the battle known as the Makassar War. The new overlords then divided up greater Gowa's empire while retaining Makassar as South Sulawesi's effective capital. In this new arrangement the VOC superintended Makassar's trade, while Sahaduddin settled in Makassar to rule South Sulawesi's internal affairs (Andaya 1981; Bulbeck 1990).

\section{Methodology}

My primary database consists of five texts, available as translations into Indonesian, which stemmed from the development of a Makassar literary tradition during the early sixteenth century. These texts are called lontarak after the palm-leaf strips on which the first texts were composed and copied, a name which persists despite the adoption of paper by at least the seventeenth century (Cense 1966). They include the "chronicles" of Gowa (Wolhoff and Abdurrahim n.d.) and Tallok (Rahim and Ridwan 1975) which describe the succession of Gowa and Tallok rulers. A royal diary (Kamaruddin et al. 1985-86) has sporadic entries up to 1630 and numerous entries thereafter. Finally, two short texts (Bulbeck 1992) chart the Maros and Sanrabone dynasties.

While these texts do not always provide self-explanatory information, ambiguities could generally be resolved as a result of earlier research on the Makassar texts (e.g. Mukhlis 1975), scholarly studies of the coeval Bugis (e.g. Caldwell 1988) and European records (e.g. Andaya 1981), and my archaeological survey of Gowa (Bulbeck 1986-87, 1992). A very detailed picture emerges of the "Who's Who" of the Makassar world during the sixteenth and seventeenth centuries, allowing the analysis of social organization through statistically demonstrable associations. This paper presents only the most important results and accordingly I restrict the methodological discussion to the main points.

To start with, many individuals accumulated titles during life or even received a posthumous name, making it necessary to collapse the recorded names into the minimum number of clearly discrete individuals. E.g. if a person was named "Daeng x Karaeng y", and the "Daeng x" who carried out certain acts could not be clearly distinguished from the "Karaeng $y$ " who carried out other acts, then I assigned both sets of acts to the one life history of "Daeng x Karaeng y". This procedure was facilitated by constructing genealogical diagrams which attempted to situate individuals and their marriages in real time (e.g. Figure 1). For statistical purposes the only relevant individuals are adults, here defined as those individuals who cannot be shown to have died before reaching marriageable age. Definite sub-adults were excluded, firstly because they would not normally have attained their expectable titulation, and secondly because Gowa's "bureaucratic" posts were held only by adults. I then extracted those individuals who could be paired with some adult next-of-kin of known sex and title - 
whether as spouses, full siblings or parent-offspring. To these 545 individuals I added a further 14 individuals, of unknown genealogical links, who held a "bureaucratic" post (Bulbeck 1992). Various subsets of these 559 individuals can then be employed according to the topic under review.

The skeletal royal genealogy shown here (Figure 1) is incomprehensible unless the reader takes the time to understand my conventions. The symbols for individuals are stretched between upper and lower points which represent dates of birth and death. Marriages are shown by horizontal lines whose vertical position marks when the marriage occurred. (Note that Figure 1 does not distinguish between recorded dates and my estimates.) Sometimes the spouses could not be juxtaposed and so the "lines of marriage" cross symbols standing for other individuals, as indicated by the horizontal lines which intrude into a symbol from either side. Individuals resulting from a depicted marriage are joined by a vertical line to the line of marriage. When only one parent is depicted, descent is shown by slanting lines, including slanted bifurcations for full siblings.

Secondly, my analysis relating marriage strategies to political change will use the concept "lineage group" (see Map 1). These "lineage groups" constitute a heuristic device for dividing up the world of socially significant individuals as seen from the vantage of the Makassar royalty. The term is deliberately ambiguous to accommodate status lineages within a descent group, descent groups, and aggregates of descent groups.

\section{Makassar Titles and Their Wider Equivalents}

To understand greater Gowa's socio-political organization we should first describe the Makassar titulation system (Bulbeck 1992; cf. Mukhlis 1975 and Röttger-Rössler 1989:45-46).

A. Areng kale - the personal name or birth name.

B. Areng padaengang - the "Daeng" title, virtually the highest title which a commoner could receive but bestowed on aristocrats at an early age. Rarer variants denoting a comparable status include the "Kare", "Lokmok" and "Gelarang" titles.

C. Areng pakkaraengang — the "Karaeng" title. This distinctly aristocratic title could be translated as "chief". Bugis equivalents included the "Arung" and "Datu" titles.

D. Lesser raja titles. I use the term "raja" to distinguish the main chiefs who exercised authority over a body of lesser chiefs. Even the lesser rajas (or petty royalty) were recognized, at least theoretically, as independent white-blooded rulers by the major kingdoms. Some lesser rajas were distinguished by their titles, e.g. the Bugis Ratu who ruled Bulo-Bulo, and the sixteenth century Makassar entitled Karaengloe ("great chief"), Somba and Tumakgauka. Other lesser rajas belonged to historical dynasties, e.g. 
Sanrabone, Maros (Bulbeck 1992), Siang (Pelras 1977), Agongnionjok (Kallupa 1984), the "Limae Ajattappareng" confederation (Caldwell 1988), and Laikang (cf. Kamaruddin et al. 1985-86:169; Andaya 1981:128, 137).

E. Greater raja titles. Three royal families — Luwuk, Gowa and Tallok became formal sultanates after voluntarily embracing Islam at the beginning of the seventeenth century. Gowa's lesser allies, Sanrabone and Bulo-Bulo, did not become sultanates, indicating a distinction between the major and the lesser pro-Gowa royalty. As for the three major Bugis agrarian kingdoms - Bone, Soppeng and Wajok - they initially eschewed the title of sultan for their ruler, presumably as a reaction to their forced conversion to Islam. But the Bone and Soppeng rulers were undoubtedly on a par with the sultans as shown by their triumph in the Makassar War.

Prior to Islamization, great Makassar rulers were distinguished by a nickname ("Tu-" or "person", followed by a passive verbal form) commemorating some highlight of their reign. All of the late fifteenth to late sixteenth Gowa rulers received such a nickname (apart from the deified Batara Gowa), as did some Tallok, Maros and Sanrabone rulers (Figure 1). Analogously the Makassar royal diary nicknames Bone's Sultan Sahaduddin as "Tunisombaya" (Kamaruddin et al. 1985-86). The only other person remembered by a nickname was Tuniawanga ri Kalassakanna, the main wife of Sultan Abdullah, the latter arguably the highest status Makassar man who ever lived.

The greater rajas, then, are the sultans, the rulers of Bone and Soppeng, and the nicknamed individuals. The sultans also include, further afield, the seventeenth century rulers of Bima and Sumbawa (Noorduyn 1987).

F. Tumenanga - the posthumous name. From at least the sixteenth century various prominent Makassar individuals received a posthumous name which usually indicated where they had died. These posthumous names reflect historical prominence rather than socially sanctioned status (Bulbeck 1992) and are not relevant here.

The Makassar titles were incremental, with duplications of titles as well as higher titles reflecting enhanced status. E.g. Sultan Abdullah's full name was “Palakkaya I Malingkaeng I Daeng Mannyori Karaeng Matoaya Karaeng Kanjilo Karaeng Segeri Sultan Abdullah Awalul Islam Tumenanga ri Agama Tumenanga ri Bonto Biraeng" (Rahim and Ridwan 1975:14-15; Wolhoff and Abdurrahim n.d.:70). To take a Bugis example, Sahaduddin's full name was "La Tenritatta Datu Mario ri Wawo Daeng Serang Arung Palakka Petta Malampéké Gemmekna Tounruk [Tunisombaya] Sultan Sahaduddin Matinroe ri Bontoalak" (Andaya 1981:43-44).

The Makassar titles were often associated with place names within or near my archaeological survey based in Gowa. Only one individual occupied any 
toponymic title at any time, apart from occasional instances of husbands and wives holding the same title. The frequency of toponymic association helps to elucidate the titles, as can be shown by taking every title associated with every Makassar individual within my database (see "Methodology", p.288) - e.g. Abdullah (Daeng Mannyori Karaeng Matoaya Karaeng Kanjilo Karaeng Segeri Sultan Tallok) counts as five titles. The "Gelarang" title is idiosyncratic, so we first consider the other titles shown in Table 1.

Table 1. Percentages of Makassar titles linked with toponyms

\begin{tabular}{lrrr}
\hline & Males & Females & Both Sexes \\
\cline { 2 - 4 } Gelarang $(\mathbf{6 , 0 , 6 )}$ & 100.0 & - & 100.0 \\
Kare $(\mathbf{1 1}, \mathbf{1 7 , 2 8 )}$ & 0.0 & 5.9 & 3.6 \\
Daeng $(\mathbf{9 5 , 1 0 6 , 2 0 1 )}$ & 14.7 & 22.6 & 19.9 \\
Lokmok $(\mathbf{0 , 2 3 , 2 3 )}$ & - & 26.1 & 26.1 \\
Karaeng (138,91,229) & 86.2 & 80.2 & 83.8 \\
Lesser Raja (26,5,31) & 100.0 & 60.0 & 93.5 \\
Greater Raja (23,1,24) & 100.0 & 0.0 & 95.8 \\
\hline
\end{tabular}

N.B. The first figure inside the brackets shows the number of male titles, the second figure shows the number of female titles, and the third figure shows the total cases. The Gelarang title departs from the usual pattern (see text).

Several associated trends emerge. The higher the title, the greater the proportion of male titulars, and the more frequent the association with a toponym. Analogously, whereas women held lesser titles in association with a toponym more frequently than men did, this relationship was reversed with the Karaengs. Not only that, but all of the male rajas ruled a kingdom while half the female rajas were honorary recipients.

Essentially, a lesser toponymic title merely linked the individual with some community. Take for instance the "Lokmok" title, which was typically associated with women of common origin who had acquired status as the secondary wife of a raja and other high status man. All but one of the six associated toponyms (cf. Table 1) refers to some wife of a Tallok raja and falls within the area which he ruled (Bulbeck 1992). (Male Lokmok are not relevant here, because their next-of-kin were never recorded and none held a "bureaucratic" post.)

Toponymic karaengships, on the other hand, identified the chiefs of land-holding communities in the most densely populated areas. Thus Mukhlis (1975:42-44,64) states that the community was required to provide its Karaeng with a suitable residence, manpower and the necessities of life. While the number of female Karaengs rivalled the number of male Karaengs, the former were associated with smaller karaengships such as places within palace centres, and never with the largest and most populous karaengships such as Garassik and Galesong (Bulbeck 1992).

The Gelarang present a complementary pattern. Originally these were the nine district headmen who represented the Gowa populace in its dealings with 
the raja, and constituted Gowa's highest council of customary law (Mukhlis 1975). However, by the mid-sixteenth century a distinction had emerged between the "inner Gelarang" (Mangasa and Tombolok) and the "outer Gelarang". The former were important officials who represented districts which also supported Karaengs, while the latter represented the wider area which provided Gowa's surplus produce and deepest reservoir of manpower (Bulbeck 1992).

During the mid-sixteenth century Gowa also developed an exclusively male "bureaucracy" of non-territorial posts, as detailed by Mukhlis (1975) and Bulbeck (1992). The most important was the regency or Tumabicara Butta (TBB in Figure 1). Several regents were also rajas, and the long-serving regents all became greater Gowa's real authority. The other posts were originally held by prominent commoners, but over time tended to be occupied by Karaengs. The Tumailalang or Ministers for Internal Affairs were members of the central court who mediated between Gowa's council of customary law and the central court. The Tumakkajannangngang or guildmaster headed the guilds which were responsible for specialist crafts (e.g. construction and weaponry) and certain designated duties. The harbourmaster was responsible for maintaining the security of the Makassar entrepôt and collecting port duties.

Gowa (and later greater Gowa) thus had a male-dominated socio-political structure linked across four substructures. The Gelarang represented a system of agrarian administration which was in place before Gowa's expansion. The "bureaucrats" belonged to a state-sponsored administration postdating Gowa's initial expansion. The lesser territorial chiefs (toponymic Karaengs) managed greater Gowa's ongoing manpower requirements, usually but not necessarily under the immediate jurisdiction of a raja. Individuals belonging to one or more substructures were ranked within a single status hierarchy by means of the Makassar titulatory system.

This status hierarchy could be extended to titled individuals from non-Makassar polities by recognizing where they would rank within the Makassar system. Accordingly foreign dignitaries could be received properly and suitable marriages arranged with non-Makassar élite individuals.

\section{Correlations in Titulation Across Next-Of-Kin}

The interrelationship between nobility of birth and access to titles can be explored by comparing titulation across next-of-kin. Here we consider the 545 Makassar and non-Makassar adults who could be paired with some next-of-kin of known sex and title (see "Methodology"). After ranking the individuals according to the highest title accredited to them in the records, we have 264 males and 281 females distributed across the titulatory ranks as shown in Table 2 . The systematic bias against women in the titulatory stakes is even clearer here than in Table 1. 
Table 2. Cross-tabulation of titles against sex

\begin{tabular}{llrrr}
\hline & & Males & Females & Both Sexes \\
\cline { 3 - 5 } Rank 1 & (Greater Rajas) & 44 & 1 & 45 \\
Rank 2 & (Lesser Rajas) & 35 & 6 & 41 \\
Rank 3 & (Karengs) & 119 & 87 & 206 \\
& / Daengs + Gelarang & 39 & 79 & 118 \\
Rank 4 & - Kare & 9 & 13 & 22 \\
& ( Lokmok & 0 & 18 & 18 \\
Rank 5 & (Untitled) & 18 & 77 & 95 \\
Total & & 264 & 281 & 545 \\
\hline
\end{tabular}

To compare titles across next-of-kin, we could use those shown in Table 2 . But to avoid the unnecessary multiplicity of categories, we pool the titles into the broader ranks of rajas, Karaengs and non-chiefs (Tables 3-1 to 3-8). Ten main points result.

1. Sons attained the rank of their father or a lesser rank, but a higher rank in only 4/155 cases (Table 3-1).

2. Therefore the great majority of rajas belonged to unbroken royal patrilines (see Figure 1), and the great majority of male Karaengs were sons of rajas or male Karaengs.

3. Daughters generally attained a rank lower than their father's (115/138 cases), and attained a higher rank in only one case (Table 3-2).

4. Therefore the great majority of female Karaengs were daughters of rajas (Table 3-2).

5. Sons usually attained the rank of their mother or a higher rank, and a lower rank in only 10/103 cases (Table 3-3).

6. Ranks were equally distributed across mothers and daughters, with a weak tendency for mothers and daughters to hold the same rank (Table 3-4).

7. Brothers' ranks show virtually no correlation (Table 3-5). 
Table 3. Comparisons of titulation across next-of-kin

\begin{tabular}{|c|c|c|c|c|c|}
\hline & & & 3-1. FA & R IS & \\
\hline & & Raja & Karaeng & Non-chief & Sum \\
\hline $\mathbf{S}$ & & & & & \\
\hline 0 & Raja & 54 & 2 & 0 & 56 \\
\hline $\mathbf{N}$ & Karaeng & 30 & 36 & 2 & 68 \\
\hline & Non-chief & 17 & 12 & 2 & 31 \\
\hline I & & & & & \\
\hline S & Sum & 101 & 50 & 4 & 155 \\
\hline D & & & 3-2. FA & R IS & \\
\hline A & & Raja & Karaeng & Non-chief & Sum \\
\hline U & & & & & \\
\hline G & Raja & 5 & 1 & 0 & 6 \\
\hline H & Karaeng & 54 & 10 & 0 & 64 \\
\hline $\mathbf{T}$ & Non-chief & 27 & 34 & 7 & 68 \\
\hline E & & & & & \\
\hline $\mathbf{R}$ & Sum & 86 & 45 & 7 & 138 \\
\hline & & & 3-3. MO & R IS & \\
\hline & & Raja & Karaeng & Non-chief & Sum \\
\hline $\mathbf{s}$ & & & & & \\
\hline 0 & Raja & 8 & 13 & 13 & 34 \\
\hline $\mathbf{N}$ & Karaeng & 4 & 12 & 30 & 46 \\
\hline & Non-chief & 2 & 4 & 17 & 23 \\
\hline I & & & & & \\
\hline $\mathbf{S}$ & Sum & 14 & 29 & 60 & 103 \\
\hline D & & & 3-4. MO & R IS & \\
\hline A & & Raja & Karaeng & Non-chief & Sum \\
\hline $\mathbf{U}$ & & & & & \\
\hline G & Raja & 0 & 2 & 2 & 4 \\
\hline H & Karaeng & 7 & 26 & 19 & 52 \\
\hline $\mathbf{T}$ & Non-chief & 0 & 14 & 29 & 43 \\
\hline E & & & & & \\
\hline $\mathbf{R}$ & Sum & 7 & 42 & 50 & 99 \\
\hline & & & 3-5. BRO & R IS & \\
\hline B & & Raja & Karaeng & Non-chief & Sum \\
\hline $\mathbf{R}$ & & & & & \\
\hline 0 & Raja & 18 & 19 & 7 & 44 \\
\hline $\mathbf{T}$ & Karaeng & 19 & 18 & 12 & 49 \\
\hline H & Non-chief & 7 & 12 & 10 & 29 \\
\hline E & & & & & \\
\hline $\mathbf{R}$ & Sum & 44 & 49 & 29 & 122 \\
\hline & & & 3-6. BRO & R IS & \\
\hline & & Raja & Karaeng & Non-chief & Sum \\
\hline $\mathbf{s}$ & & & & & \\
\hline I & Raja & 1 & 0 & 0 & 1 \\
\hline $\mathbf{s}$ & Karaeng & 30 & 22 & 12 & 64 \\
\hline $\mathbf{T}$ & Non-chief & 3 & 25 & 10 & 38 \\
\hline$E$ & & & & & \\
\hline $\mathbf{R}$ & Sum & 34 & 47 & 22 & 103 \\
\hline
\end{tabular}




\begin{tabular}{|c|c|c|c|c|c|}
\hline & & & 3-7. SIS & IS & \\
\hline & & Raja & Karaeng & Non-chief & Sum \\
\hline S & & & & & \\
\hline I & Raja & 0 & 1 & 0 & 1 \\
\hline S & Karaeng & 1 & 30 & 8 & 39 \\
\hline $\mathbf{T}$ & Non-chief & 0 & 8 & 24 & 32 \\
\hline E & & & & & \\
\hline $\mathbf{R}$ & Sum & 1 & 39 & 32 & 72 \\
\hline & & & 3-8. HUS & ID IS & \\
\hline w & & Raja & Karaeng & Non-chief & Sum \\
\hline I & & & & & \\
\hline$F$ & Raja & 7 & 2 & 0 & 9 \\
\hline E & Karaeng & 49 & 50 & 2 & 101 \\
\hline & Non-chief & 76 & 76 & 43 & 185 \\
\hline I & & & & & \\
\hline $\mathbf{S}$ & Sum & 132 & 128 & 45 & 305 \\
\hline
\end{tabular}

N.B. In these tables the summed figures show the number of cases of reconstructible relationships, not the number of individuals involved in the comparison. The latter figure is less than the former except for offspring who of course could have no more than one parent of any sex (Tables 3-1 to 3-4).

8. Sisters mostly attained a rank lower than their brothers', and a higher rank in only 12/103 cases (Table 3-6).

9. Sisters tended to attain the same rank (Table 3-7); indeed, as can be demonstrated through formal statistical analysis (Bulbeck 1992), no other next-of-kin showed such strong titular correlation.

10. Wives were either ranked below or at the same level as their husband, and in only 4/305 cases did women marry a lower ranked man (Table 3-8). This holds despite the high divorce rate which, along with the frequency of marriages noted in the royal diary (Kamaruddin et al. 1985-86) between individuals who are otherwise absent from the records, and the practice of élite polygyny, explains why so many marriages are on record. (While Tables 3-1 and 3-8 suggest 132 wives for 56 male rajas, and 128 wives for 68 male Karaengs, these totals understate the level of élite polygyny. This is especially true for the rajas, many of whose wives went unnamed or were even noted as too numerous to list.)

It is formally impossible that Tables 3-1 to 3-8 could describe a closed system. As fathers, and to a lesser degree as husbands, rajas figure prominently, Karaengs figure less prominently, and non-chiefs hardly at all. Yet as sons and as brothers these three categories are similarly represented. This paradox rests on two points. Rajas usually had many more wives (often of common origin) than the male Karaengs did, and hence more offspring. Undoubtedly, also, male Karaengs had more wives and offspring than male non-chiefs did. But the supporting evidence is unavailable because the genealogical records hardly mention male non-chiefs except in their capacity as sons of high status men. This brings us to the second point; regardless of their birth, men who did not attain karaengships exited 
beyond the pale of genealogical significance. And many well born sons failed to earn high titles, explaining the lack of correlation between brothers' titles.

The strong correlation between sisters' titles agrees with the ethnographic observation that women's titles were strongly ascribed by birth. This might appear to support the idea that women (as principal wives) tended to mark the status which the husband attained, and that individuals inherited their nobility (and hence their access to titles) fairly equally from both parents. But the highest status, royal titles were usually restricted to patrilineal descendants, even if the mother's birth helped to rank candidates' chances. Furthermore women were systematically demoted compared to their male next-of-kin, so an equality of titles between sisters had only loose implications for their husbands' or sons' titles. All in all, statistical analysis shows that the father's title was between two to three times more influential than the mother's, regardless of the sex of the offspring (Bulbeck 1992).

\section{Horizontal Links Between the Royal Cores}

While marriages were closely linked with political solidarity and alliance, political considerations often changed rapidly and flexible marriage strategies had to be followed. One component of this flexibility derived from the systematic demotion of women's status, so that even princesses could marry a wide range of aristocrats. The other component stemmed from the Makassar's eschewal of prescriptive or preferential marriage, as indicated by the enormous sweep of consanguineal relationships which, from my database, can be reconstructed between wives and their related husbands.

Far more relationships trace their closest common ancestor through step siblings born of a single polygynous man (Table 5) than to a conjugal pair (Table 4). Since divorces occurred frequently, we might expect that some of the consanguineal spouses shared, as their single closest common ancestor, a woman who mothered children to different men; but I could not find any examples. Both points emphasize the structural importance of noble and especially royal polygyny.

Because almost all male rajas belonged to an unbroken royal patriline, a mala raja rarely married a related woman unless their closest common ancestry involved one of the raja's royal forefathers. 28/55 of the marriages between recorded relations were of this type. The royal forefather was two generations back on both sides in 13 cases and no more than three generations back on either side in 23 cases. That is, the royal lines frequently intermarried (Figure 1) to maintain their position as the ruling class distinct from the nobility. Men removed from a royal core could strive to marry a raja's daughter, but the enhancement of their own prospects then became dependent on the authority of the daughter's 
royal core. The Malay ruling class maintained its central position in the same way (Gullick 1958).

Table 4. Relationship of wife to her related husband (where a conjugal pair forms the closest common ancestors)

\begin{tabular}{|c|c|c|c|c|c|c|c|c|}
\hline HUSBAND IS & Raja & Raja & Raja & Raja & Karaeng & Karaeng & Karaeng & Sum \\
\hline WIFE IS & Raja & Karaeng & Daeng & Untitled & Karaeng & Daeng & Untitled & \\
\hline FZD \& MBD & & 2 & & & & & & 2 \\
\hline FZD & 1 & 2 & & & & & 1 & 4 \\
\hline MBD & & 1 & & 1 & & & & 2 \\
\hline FBD & & 1 & 1 & & 2 & 1 & & 5 \\
\hline FBSD & 1 & & & & & & & 1 \\
\hline FFBD & & 1 & & & & & & 1 \\
\hline FFBSSD & & 1 & & & & & & 1 \\
\hline MFMBSD & & & 1 & & & & & 1 \\
\hline FFFZSDSD & & & 1 & & & & & 1 \\
\hline Sum & 2 & 8 & 3 & 1 & 2 & 1 & 1 & 18 \\
\hline
\end{tabular}

N.B. The "FZD \& MBD" relationship involved three common grandparents.

Table 5. Relationship of wife to her related husband (closest ancestry traced via step siblings)

\begin{tabular}{|c|c|c|c|c|c|c|c|c|c|}
\hline $\begin{array}{l}\text { HUSBAND IS } \\
\text { WIFE IS }\end{array}$ & $\begin{array}{l}\text { Raja } \\
\text { Raja }\end{array}$ & $\begin{array}{l}\text { Raja } \\
\text { Karaeng }\end{array}$ & $\begin{array}{l}\text { Karaeng } \\
\text { Raja }\end{array}$ & $\begin{array}{l}\text { Raja } \\
\text { Daeng }\end{array}$ & $\begin{array}{l}\text { Raja } \\
\text { Untitled }\end{array}$ & $\begin{array}{l}\text { Karaeng } \\
\text { Karaeng }\end{array}$ & $\begin{array}{l}\text { Karaeng } \\
\text { Daeng }\end{array}$ & $\begin{array}{l}\text { Karaeng } \\
\text { Untitled }\end{array}$ & Sum \\
\hline FFDD \& MFSD & & & & & & 1 & & & 1 \\
\hline FFDD & & & & & & 1 & & & 1 \\
\hline MFSD & & 1 & & 1 & & 2 & & 1 & 5 \\
\hline FFSD & & & & 1 & & 1 & & 1 & 3 \\
\hline MFDD & & & & 1 & & & & & 1 \\
\hline FFFSD & & & & & & & 1 & & 1 \\
\hline FFSDD & & & & & & & 1 & & 1 \\
\hline FFSSD & 1 & & & & & & & & 1 \\
\hline FFDSD & & 1 & & & & 1 & & & 2 \\
\hline FFDDD & & 1 & & & & & & & 1 \\
\hline FMFSD & & & & 1 & & & 1 & & 2 \\
\hline FFFSSD & & & & & & 1 & & & 1 \\
\hline FFFSDD & & & & & & 1 & & & 1 \\
\hline FFFDSD & 1 & & & 1 & & & & & 2 \\
\hline FFFDDD & & 1 & & & 1 & & & & 2 \\
\hline FMFSSD & & & & & & 1 & & & 1 \\
\hline FMFSDD & & & & 1 & & & & 1 & 2 \\
\hline FFFSSSD & & & 1 & & & & & & 1 \\
\hline FMFSSSD & & 1 & & & & & & & 1 \\
\hline MFFDSSD & & & & & & 1 & & & 1 \\
\hline FFMFSSSD & & & & & & 2 & & & 2 \\
\hline FFMFSSDD & & & & 1 & & & & 1 & 2 \\
\hline FMFFDSSD & & & & & & 1 & & & 1 \\
\hline FMFFDSSSD & & & & & & 1 & & & 1 \\
\hline Sum & 2 & 5 & 1 & 7 & 1 & 14 & 3 & 4 & 37 \\
\hline
\end{tabular}

N.B. "FS" stands for father's son's, i.e. step-brother's, and "FD" stands for father's daughter's, i.e. step-sister's. The "FFDD \& MFSD" relationship involved two polygynous grandfathers as the equally closest common ancestors. 


\section{Makassar Status Lineages}

To summarize the foregoing, male patrilines constituted the vertical structure within Makassar aristocratic genealogical space. Women of various origins entered into the structure with increasing frequency towards the top. The superfluous proportion of well-born sons were banished from contention. The daughters generally entered into élite marriages, creating horizontal links within the genealogical space. But these horizontal links supported rather than bound the men at the top of the hierarchy.

Table 6. Status and patrilineality of male-dominated posts

\begin{tabular}{lllllc}
\hline & $\begin{array}{c}\text { Greater Raja } \\
(\%)\end{array}$ & $\begin{array}{c}\text { TITLE HOLDER IS: } \\
\text { Lesser Raja } \\
(\%)\end{array}$ & Karaeng (\%) & Nonlord (\%) & $\begin{array}{c}\text { \% WHO WERE } \\
\text { SONS OF } \\
\text { TITLE-HOLDING } \\
\text { FATHER }\end{array}$ \\
\hline Gowa Raja $(\mathbf{n}=\mathbf{1 5})$ & 100 & 0 & 0 & 0 & 86.7 \\
Tallok Raja $(\mathbf{n}=\mathbf{1 1})$ & 81.8 & 18.2 & 0 & 0 & 81.8 \\
Maros Raja $(\mathbf{n}=\mathbf{4})$ & 50.0 & 50.0 & 0 & 0 & 75.0 \\
Sanrabone Raja $(\mathbf{n}=\mathbf{9})$ & 27.3 & 72.7 & 0 & 0 & 88.9 or 55.6 \\
& & & & & (see below) \\
Regent $(\mathbf{n}=\mathbf{7})$ & 42.9 & 0 & 57.1 & 0 & 42.8 \\
Tumailalang $(\mathbf{n}=\mathbf{1 4})$ & 0 & 0 & 85.7 & 14.3 & 26.7 \\
Guildmaster $(\mathbf{n}=\mathbf{4})$ & 0 & 0 & 50.0 & 50.0 & 25.0 \\
Harbourmaster $(\mathbf{n}=\mathbf{1 2}$ & 0 & 0 & 16.7 & 83.3 & 0 \\
\hline
\end{tabular}

N.B. These figures ignore inaugural occupants who obviously could not have inherited the post from their father. Statistics for the Makassar thrones are taken from Figure 1, and count Batara Gowa (G7) as a "greater raja". The last three seventeenth century regents, and Gowa's other non-territorial administrators, are not shown in Figure 1 but are documented elsewhere (Bulbeck 1992).

Thus the Makassar élite practised a type of apical demotion which depended structurally on patrilinealism and polygyny as élite privileges. To see how privileged this patrilinealism was, consider the very strong association between the status of a title (as measured by the status of the title holders) and the degree to which the title was inherited patrilineally (Table 6). Far from being a principle which included related individuals within a descent group, patrilineal descent was used by a higher status lineage specifically to exclude related men whose father belonged to a lesser lineage.

Just because a man was barred from membership within status lineages higher than his father's, this did not guarantee him automatic membership within his father's status lineage. On the contrary, apical demotion involves the continual reassessment of "ascribed status" depending on achievement. A man who failed to earn the required status lost his (potential) natal membership and either started a new status lineage or married into a lesser status lineage.

To take the example of the sons of a Gowa (or other Makassar) raja, any son who failed in the succession concurrently lost any direct claim on the title for his sons, and so began a new patriline. Therefore the only men included in a 
royal status lineage are those belonging to the patriline of rajas, including all the installed brothers.

Furthermore, any man who failed to attain a karaengship virtually guaranteed that his descendants would be banished to genealogical insignificance. So the only men included in a noble status lineage linked to the Gowa royal line are those who can trace a direct line of male Karaengs back to the son of a Gowa raja. They could also have traced an ambilineal line of ancestry into other lineages, but this would have been pointless since the Gowa royalty constituted the highest status Makassar lineage. We would also expect the Gowa nobility to exclude from their ranks any nobles directly descended from lines inferior to Gowa's, and this expectation is confirmed by the genealogical distribution of the major noble titles (Figure 2).

Where do women fit into a genealogical system based essentially on men's titles? For two reasons I assign women to their father's status lineage even if the mother's was higher. Firstly, the father's title was the major influence on the offspring's title irrespective of gender, and the systematic demotion observed in the opposite-sex next-of-kin comparisons held true between brothers and sisters. Secondly, the notion that women should marry at their own level or upwards implies that the husband enjoyed either equal or greater authority.

It is not even necessary to assume that daughters left their father's status lineage upon marriage. Indeed the frequency of divorces, and the occasional instances of women marrying within their own status lineage (Bulbeck 1992), suggest that many women never did. However, the offspring were born within their father's status lineage, either as potential members in the case of boys, or as members to be strategically married in the case of girls. This and the other points discussed above will become clearer during the description of my 17 "lineage groups" (see Map 1) and the associated status lineages.

\section{Makassar Lineage Groups}

Gowa Core. All of the sixteenth and seventeenth century Gowa rajas (plus their daughters).

Gowa Nobility. All of the Karaengs (plus their daughters) patrilineally descended from a Gowa raja. Whether we consider them a single status lineage or a group of closely related status lineages is irrelevant. The important point is that their fortunes closely followed those of the Gowa royalty (see below).

Tallok Core. All of the sixteenth and seventeenth century male Tallok rajas, plus their daughters (including Tallok's only queen), but excluding Tunipasuluk (G13/T6/m5 in Figure 1) who belonged to the Gowa core. Tallok's origins would make Tallok a branch within the Gowa nobility (Figure 1) except that the Tallok core constituted an independent line of rajas. 


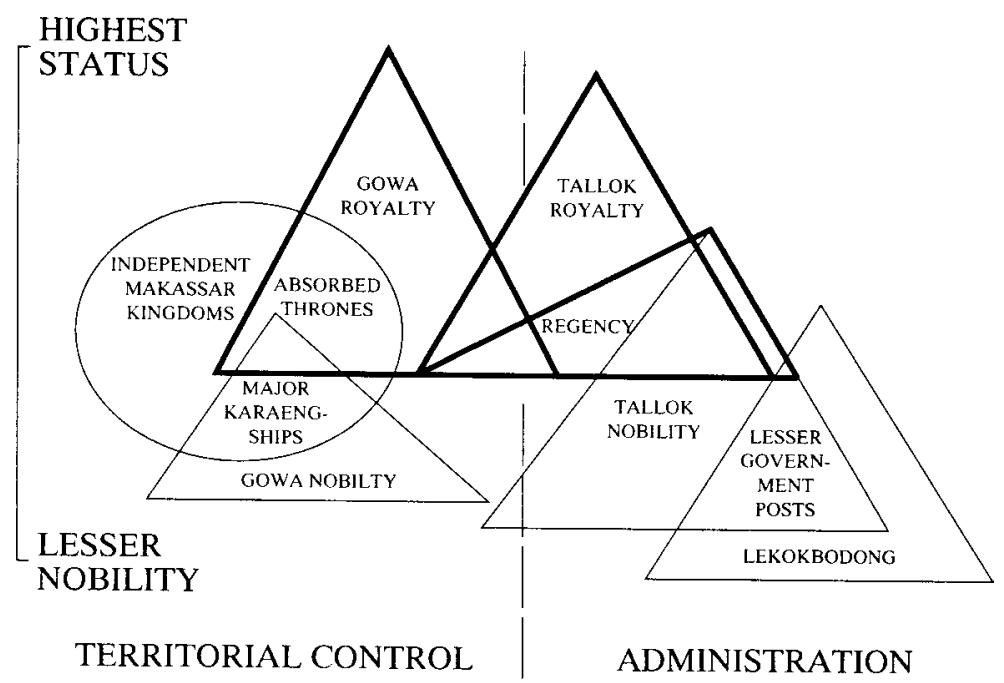

Figure 2. Schematic representation of Greater Gowa's organization.

Tallok Nobility. See "Gowa Nobility" above.

Gelarang. Previously I had discussed the Gelarang in relation to Gowa, but a similar arrangement also existed in Tallok. The texts occasionally mention marriages involving the families of the Gowa or Tallok Gelarang. These are pooled into a "Gelarang" group for convenience since I have no data on their descent principles.

Garassik. The earliest detailed Makassar historical accounts identify Garassik as a former port-polity which had been reduced to a patch of prime real estate by the early sixteenth century (see "Background to Gowa"). Garassik first lost its independence after an unnamed daughter ("?" in Figure 1) of Somba Garassik (gl) married Batara Gowa (G7) and gave birth to a Gowa noble who later ruled Garassik (g2, i.e. Karaeng Barataua Karaeng Garassik). Before losing its independence Garassik was also involved in some other marriage exchanges (Table 7). After the late sixteenth century the Garassik karaengship came to be held by one Tallok noble and various Gowa nobles.

Polombangkeng. Polombangkeng had consisted of an umbrella of seven "brother kings" headed by Bajeng and including Jamarang, Mandallek, Katingang, Jipang, Sanrabone and Lengkesek. The west Polombangkeng members - Katingang, Jipang, Sanrabone and Lengkesek — were punished by Gowa during the mid-sixteenth century for having earlier assisted Tallok's unsuccessful attempt to retake Garassik from Gowa (Bulbeck 1992). At around this juncture Jamarang, Mandallek and Katingang were also involved in documented marriages with Gowa and with certain local Makassar karaengships. Circumstantial evidence suggests that these three Polombangkeng polities then supported patrilineal 
cores, even if they were also attached to Bajeng as their central royal line (Bulbeck 1992).

Sanrabone. Although originally one of the west Polombangkeng polities humiliated by Gowa in the mid-sixteenth century, in the late sixteenth century Sanrabone rose to fill the power vacuum created by the demise of Bajeng. Sanrabone retained its prominence until the death of Tumenanga ri Campagana (s6 in Figure 1) in 1642. The next two Sanrabone rulers died within five years, amidst such chaos that two quite different successions appear equally possible from the records (Bulbeck 1992). In one interpretation, rulership first passed to Campagana's full brother Karaeng Bambanga (s7?), and then patrilineally from Campagana to his son Tumenanga ri Buttana (s8?) and grandson Puanna Jenalak (s9). In the other interpretation rulership passed to Campagana's daughter Karaenga Pucu (s7?) and to her son Karaeng Banyuanyarak (s8?) before passing back to Puanna Jenalak (s9). Anyway, Puanna Jenalak was expelled in 1658. After an interregnum lasting a decade, Karaeng Campagaya (later Sultan Abdul Jalil), the son of Gowa's Sultan Hasanuddin (G16/TBB4) by the daughter of Karaeng Banyuanyarak, was installed as Sanrabone's raja (Figure 1). Hitherto Sanrabone had supported a royal patrilineal core, even if chaos in the 1640s conceivably led to some irregular appointments and ultimately to Sanrabone's absorption by Gowa.

Minor Makassar. The records are dotted with references to marriages involving local Makassar nobility or petty Makassar royalty not descended from the major lines (Bulbeck 1992). These include Anak Sappuk, Bangkala, Kasuarrang, Bungaya, Beroanging, Laikang, Batu-Batu, Pattung and seventeenth century Mandallek (Map 1), as well as three which cannot be unambiguously located (Paria, Pabolik and Bontomanaik). I have only the sketchiest data on the succession to these karaengships, none of which forms a cohesive unit of analysis by itself. They can be pooled for present purposes.

Pattekne. The title of Karaeng Pattekne recurs throughout the records and so Pattekne stands apart from the other minor noble Makassar lines. From the late sixteenth century the title was held by men, apparently not descended from the major lines, who furthermore held one stream of the Tumailalang posts until the mid-seventeenth century (Bulbeck 1992).

Maros. The short dynasty of autonomous Maros rulers, plus their daughters (Figure 1). The last of the dynasty, Tunikakassang (m4), reportedly had no offspring. He died an old man and so probably outlived anyone else within the core. When the Gowa king Tunijallok defeated Maros during Tunikakassang's reign, he struck a treaty whereby Tunijallok's descendants would rule Maros while Tunikakassang's "descendants" (presumably his nephews and their descendants) would hold the post of Gowa Tumailalang. Tunijallok's son 
Tunipasuluk (G13/T6/m5) briefly occupied the Maros throne before Tallok's palace revolution expelled him in 1593 (Bulbeck 1992).

Lekokbodong. After Tunipasuluk, Maros failed to recover its former status as an independent kingdom. But a status lineage or group of related lineages based in Maros apparently gained major factional status within greater Gowa. A clutch of men held the recurring karaengships of Cenrana and Lekokbodong, as well as one and later two streams of the Tumailalang posts. Where it can be followed, the succession of these titles resembles the succession of the Kasepekang titles (cf. Rössler 1987 and Röttger-Rössler 1989). Kamaruddin et al. (1985-86) retain the name "Maros" for this noble house, but I prefer "Lekokbodong" to distinguish it from its predecessor.

Minor Bugis. Various minor Bugis kingdoms were fleetingly involved in marital exchanges recorded in the Makassar texts (Bulbeck 1992). They are Siang (c.1500), Suppak and Lamuru (sixteenth century), Segeri (early seventeenth century) later called Agongnionjok (late seventeenth century), and Siang, Barru, Sawitto and Sidenreng (late seventeenth century).

Bulo-Bulo. Also a minor Bugis kingdom, Bulo-Bulo had a special status owing to its location due south of Bone. Greater Gowa and its allies propped up Bulo-Bulo as a means of containing any southward expansion by Bone (Bulbeck 1992).

Luwuk. During greater Gowa's period of hegemony in South Sulawesi affairs, two of the major Bugis kingdoms, Luwuk and Wajok, were allied with Gowa. Only Luwuk is considered here because Wajok fails to appear in the genealogical records (Bulbeck 1992).

Soppeng/Bone-Soppeng. Prior to 1667 Gowa took a few wives from Soppeng (Bulbeck 1992). Bone and Soppeng jointly spearheaded the 1667 assault on Makassar, after which point Bone set about absorbing the Soppeng rulership (Bulbeck 1990). So for our purposes Bone and Soppeng can be grouped for the period after 1667, and made to include the major Bone "Arung" (Maroanging, Tanete and Teko) and Soppeng "Datu” (Belo).

Eastern Indonesia. Bima and Sumbawa, as well as some nearby kingdoms, were defeated at various times by greater Gowa between 1616 and 1626. After some revolts in the early 1630s, Bima and Sumbawa entered into regular marriages with the various factions of greater Gowa from 1646 onwards. The only recorded bride exchange involving Ternate occurred in 1672 when I Asseng, a daughter of Malikussaid (G15), married the Ternate sultan (Bulbeck 1992). All of these data are here grouped into "Eastern Indonesia".

Having defined our lineage groups, we can now relate the politics of élite marriage to (greater) Gowa's political history. While the categories "wife givers" and "wife takers" are inappropriate for the Makassar system (Fox pers.comm.), 
nonetheless we are still dealing with groups of related men who perpetuated their status lineage by attracting wives from other groups of related men. Marriage strategies can therefore be shown by cross-tabulating the father's and husband's lineage groups. Chronologically the marriages can be grouped according to the three major phases of Gowa's history during the sixteenth and seventeenth centuries (Tables 7 to 9 ).

\section{Gowa's Initial Expansion (c.1500-1593)}

In the early sixteenth century Gowa was merely one of the chiefdoms located in South Sulawesi's southwest corner. After the mid-sixteenth century Gowa expanded southwards to incorporate the northern two-thirds of Polombangkeng. When Tunipasuluk (G13/T6/m5) briefly occupied the Tallok and Maros thrones between 1590 and 1593, he commanded the largest area ever directly ruled by Gowa.

Until 1593 the great majority of the recorded marriages involved Makassar polities, and one Bugis polity (Siang), located within the southwest corner of South Sulawesi. The notable rôle played by the (Gowa) Gelarang highlights the restricted geographical range of the marriages (Table 7). True, four royal and noble women from Bugis kingdoms north of Siang married Gowa royalty (Table 7), but no offspring resulted (Bulbeck 1992).

Most of the marriages which I recorded between close relatives descended from a conjugal pair (Table 4) resulted from the series of royal marriages between Gowa and Tallok during the early to middle sixteenth century (see Figure 1). These marriages bound the fortunes of the Gowa and Tallok royalty, but at Tallok's peril since the number of princesses provided by Tallok was not reciprocated by Gowa (Table 7). When the Tallok raja Tumenanga ri Makkoayang (T4/TBB1) died in 1577, his only adult descendants were two daughters both married to the Gowa raja Tunijallok (G12). (One of the daughters, Karaeng Batu-Batu [e], may have already died, but this does not affect the argument.) Unless Tallok were to install an immature incumbent, the throne had to pass to a wife of Tunijallok. The woman appointed, Karaeng Bainea (T5), produced nine offspring but little evidence of government independent from her husband (Bulbeck 1992). Tallok was no longer in the position to exclude these offspring from the Tallok core on the basis of lacking patrilineal membership, because Tallok had become a lesser status lineage compared to Gowa. Consequently the first born son of Tunijallok and Karaeng Bainea, Tunipasuluk, claimed the Tallok throne while patrilineally inheriting the Gowa throne.

The growing status of the Gowa royalty compared to Tallok is clear from the number of brides taken by the Gowa royalty, accounting for over half of the marriages between lineage groups (Table 7). Moreover the Makassar lineage groups which produced rather than attracted wives came to fall within Gowa's 
domain. These include Garassik, an early source of brides; and Jamarang and Katingang (here included within Polombangkeng) which had provided Gowa with several royal brides. In contrast Sanrabone and Pattekne attracted wives and survived as status lineages into the seventeenth century (Tables 7 to 9).

\section{The Golden Period of Greater Gowa (1593-1667)}

Greater Gowa's heyday began in 1593 when Karaeng Matoaya (T7/TBB2), or Abdullah as he was later called, instigated the palace revolution which expelled Tunipasuluk. Because his father had been Gowa regent as well as king of Tallok (Figure 1), Abdullah had a direct claim both on Tallok and the regency. His fellow conspirators also joined the confederated power structure which blossomed particularly during the mid-seventeenth century reigns of Malikussaid and Hasanuddin (Reid 1987; Bulbeck 1992).

During the period, marriages involved a wide geographical range of lineage groups (Table 8), reflecting greater Gowa's expanded sphere of political influence. Included are Gowa's eastern Indonesian allies of Bima and Sumbawa, and Gowa's Bugis allies on the east coast, Bulo-Bulo and Luwuk. The Gelarang now hardly figured at all.

Greater Gowa's decentralized power structure is clearly reflected in the marriage patterns. The Gowa, Tallok and Lekokbodong nobilities now took a prominent part, while the frequency of daughter exchanges between the Gowa royalty and other lineage groups was reciprocal overall. Indeed the Tallok royalty provided rather than attracted wives; and by the end of the period the rulers of Gowa (Hasanuddin) and Tallok (Harrunarasyid) both had mothers whose common origin is revealed by their "Lokmok" title.

Sanrabone lost its independence during this period. Sanrabone had attracted wives during the reigns of Parallekkena (s5) and Campagana (s6), but then provided wives leading up to and during the period of chaotic succession in Sanrabone discussed above. This change is not apparent from the figures in Table 8 which are aggregated to reflect the political situation in greater Gowa rather than Sanrabone. Note that the Gowa prince who absorbed the Sanrabone throne, s10/G19 (later Sultan Abdul Jalil), was either the matrilateral grandson or matrilateral great grandson of a Sanrabone raja (depending on how we interpret Sanrabone's mid-seventeenth century succession). He could claim the Sanrabone throne based on his descent from a woman either right within or one step removed from the royal Sanrabone core.

\section{The Survivors (Post-1667)}

Our third period began when Bone and Soppeng, the two important Bugis kingdoms which suffered most under greater Gowa, joined forces with the VOC. The allies occupied Makassar in 1667 and destroyed Gowa's entrepôt palace of 
Somba Opu in 1669. In 1677 the Bone leader Sultan Sahaduddin finally snuffed out all resistance when he occupied Gowa itself. Until his death in 1696, he continued to combine diplomacy and thuggery in monopolizing power within South Sulawesi affairs to an unprecedented degree. Sahaduddin himself was childless but before his death chose a successor in his nephew Alimuddin, who along with his offspring maintained Bone's pre-eminence in local politics until the mid-eighteenth century (Andaya 1981; Bulbeck 1990).

After the Makassar War, greater Gowa virtually ceased attracting women from external status lineages and instead provided wives (Table 9). Greater Gowa's Bugis ally, Bulo-Bulo, which was immediately absorbed by Bone after the Makassar War (Andaya 1981), falls in the same pattern. The Bugis kingdoms which greater Gowa had previously dominated, some of whom had also provided greater Gowa with wives, now married greater Gowa's daughters (Table 9). In accordance with Sahaduddin's pre-eminence, Bone was dominant, but Soppeng, Siang, Agongnionjok, Sawitto and Sidenreng also drew wives from greater Gowa. So did the eastern Indonesian sultanates, now including Ternate.

Marriage patterns within greater Gowa reflect the reorganization of its internal power structure. The Gowa royalty and nobility provided wives while the Tallok royalty and especially Lekokbodong attracted wives. The Tallok nobility was especially active in both spheres (Table 9). The last point identifies the Tallok nobility as greater Gowa's "power broker", a rôle centred on Karaeng Karunrung (TBB6 in Figure 1) who was then the regent and the single most powerful Makassar man. Thus after the Tallok sultan Harrunarasyid fled in the wake of Gowa's 1677 military debâcle, Karaeng Karunrung managed to maintain the royal Tallok patriline by installing the boy sultan Abdul Kadir (Andaya 1981; Patunru 1983).

Gowa's eclipse and the rise of Tallok and Lekokbodong reflect the specializations of the various factions within greater Gowa. As detailed elsewhere (Bulbeck 1992) territorial control was primarily the province of Gowa, whereas the noble administrative posts were mostly vested in Tallok and Lekokbodong (Figure 2). The Makassar War and its aftermath grievously diminished the area under greater Gowa's jurisdiction, but without simplifying greater Gowa's administration (Bulbeck 1992). Consequently Gowa had become largely redundant to the survival of an organization whose strength now lay in its capacity to accommodate the new territorial overlords, Bone and the VOC. 
The Politics of Marriage and the Marriage of Polities in Gowa, South Sula Wesi

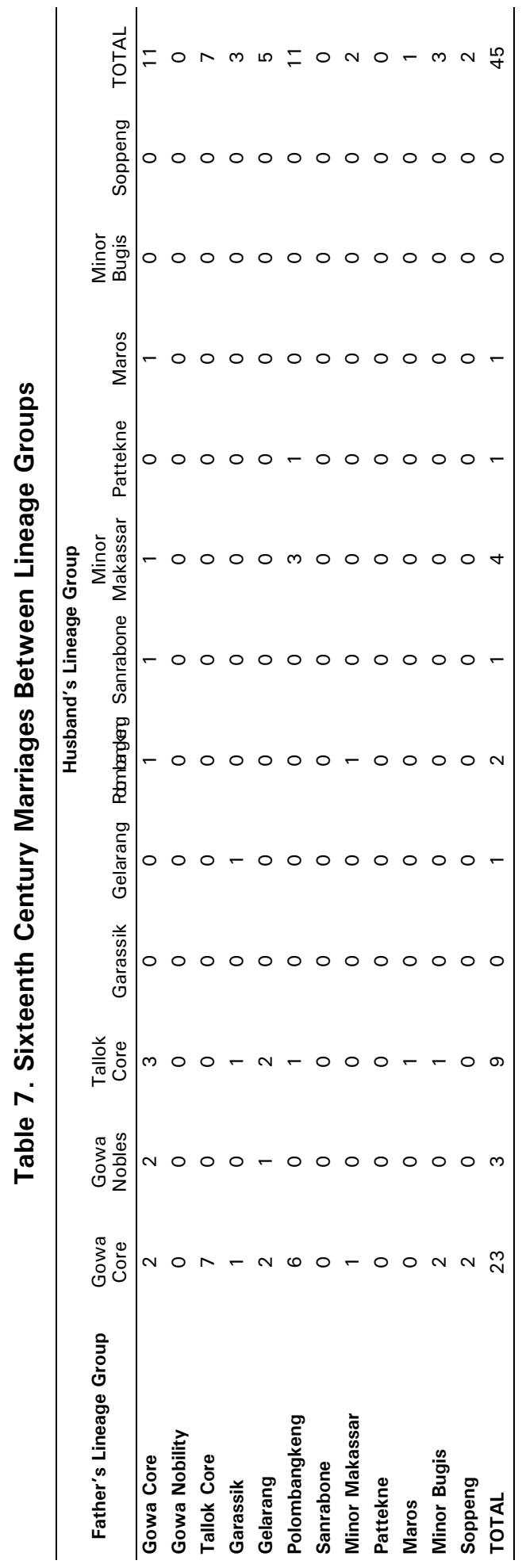


Origins, Ancestry and Alliance

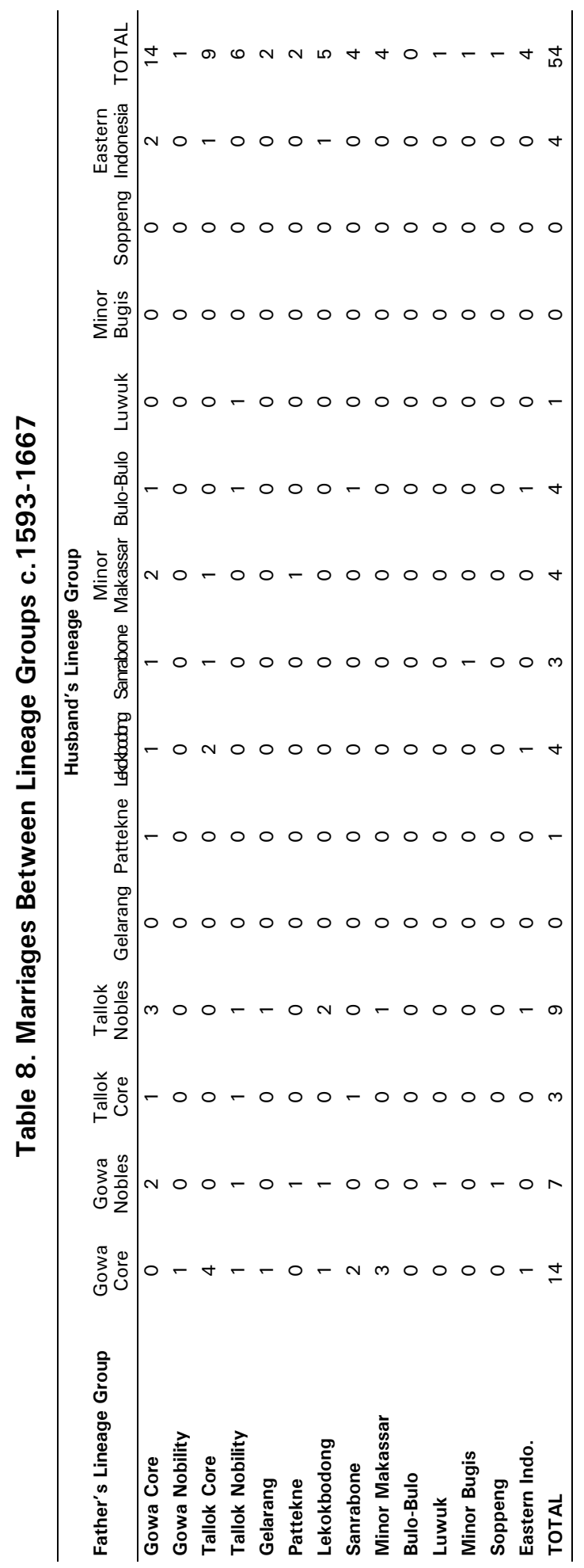


The Politics of Marriage and the Marriage of Polities in Gowa, South Sula Wesi

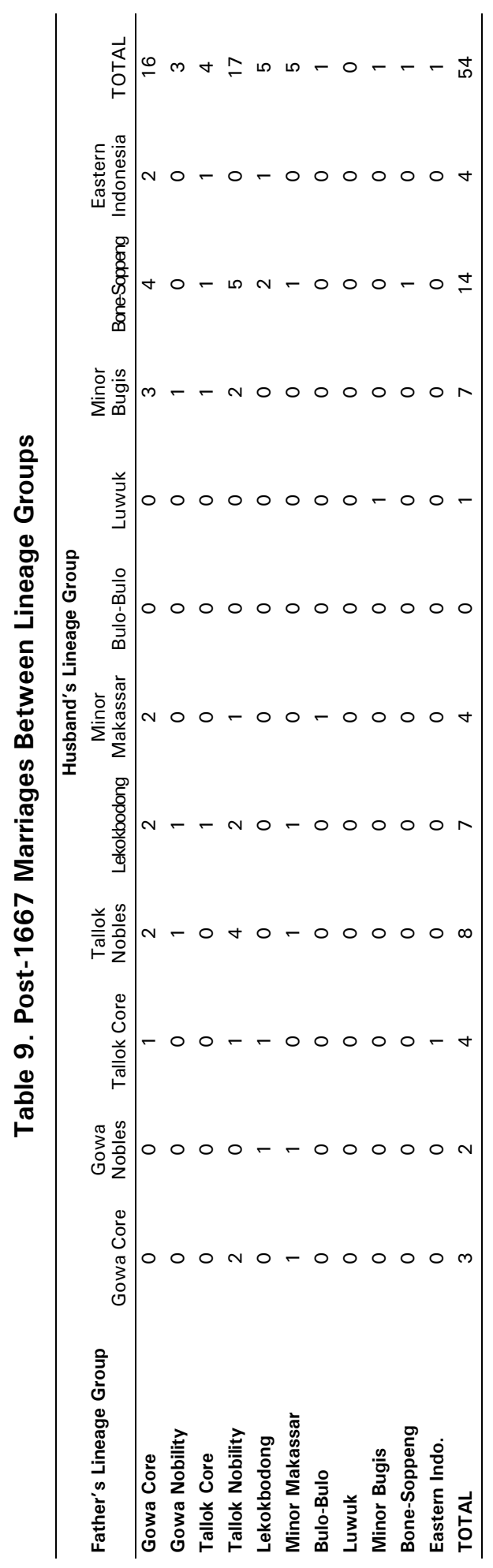


The rot set in Gowa's succession when Hasanuddin (G16/TBB4) abdicated after the destruction of Somba Opu. His chosen successor, Amir Hamzah (G17), died in 1674. Amir Hamzah's half brother, Muhammad Ali (G18), was expelled following Sahaduddin's occupation of Gowa in 1677. Stability was restored only when Muhammad Ali's full brother, Abdul Jalil (s10/G19), accepted Gowa's reduced status as the necessary price (Bulbeck 1990).

Furthermore, Hasanuddin's three successors either died as young adults or were constrained from taking many wives. They produced few children, none of them a son who survived to maturity (Figure 1). Amir Hamzah was childless. Muhammad Ali left two daughters, one of whom (Karaeng Parang-Parang, " $k$ ") married the Tallok Sultan Abdul Kadir (T11) and gave birth to Tallok's Sultan Sirajuddin (T12/G21). Abdul Jalil's only mature child, Karaeng Pattukangang (1), married Sahaduddin's chosen successor Alimuddin (B16/S17). As the (adopted) son of a Soppeng female raja, Alimuddin later absorbed the Soppeng rule. His three sons by Karaeng Pattukangang serially ruled Bone, and two also came to rule Soppeng (Bulbeck 1990).

When Abdul Jalil died in 1709, Hasanuddin's other sons were either dead or close to death, and Gowa's surviving princesses were aged (Bulbeck 1992). The Gowa royalty was vanquished as a patrilineal core and had to include princesses' sons. As South Sulawesi's most powerful lineage, Bone-Soppeng forced its claims, and Sultan Ismail (B19/S19/G20) ruled Gowa as the first of his three royal titles. But Bone-Soppeng's authority waned with the approaching death of Alimuddin. In 1714 Ismail was forced to abdicate in favour of Karaeng Parang-Parang's daughter, Sirajuddin (T12/G21). Thus the Tallok Sultan Sirajuddin, as a matrilateral grandson within the Gowa royal core from a higher status lineage, ultimately absorbed the Gowa rulership within the Tallok royalty (Bulbeck 1992).

Sirajuddin was preferred over Ismail because a Makassar royal constituted a far more palatable ruler of Gowa than a Bugis royal did (Patunru 1983:76). A fuller explanation notes the depth of Sirajuddin's ties with the Gowa royalty, compared to Ismail's which extended back only a generation (Figure 1). Further, very many Makassar nobles were related one way or another to Sirajuddin, and the late seventeenth century flurry of marriages between Bone-Soppeng and greater Gowa was inadequate to repair the difference. This point highlights a key strength of the bilateral component of élite Makassar kinship. Usurpation of a royal title from above could be briefly successful, but it could only be sustained if the appropriate breadth and depth of relationships with the subjects were also established. 


\section{Conclusions}

Statistical analysis of the data clarifies the nature and transmission of élite Makassar titles during the sixteenth and seventeenth centuries. The results strikingly resemble those obtained by Palmier (1969) for traditional Java and Gullick (1958) for the western Malaysian states. But the closest parallel comes from the system documented by Rössler (1987) and Röttger-Rössler (1989) for the Kasepekang Konjo. Moreover our sparser data sets, such as those pertaining to Polombangkeng and Lekokboding, invoke the Konjo model, even if the available details are inadequate for rigorous comparisons.

The key institutions were the bilateral descent groups composed of descendants of the inaugurators of hereditary titles. The most powerful of these were associated with a royal title closely guarded by a patrilineal core. Royal polygyny at the centre generated a bank of potential princes who ensured uninterrupted patrilineal passage of the title. Ipso facto it also generated unsuccessful candidates who, along with their patrilineal descendants, maintained a recognized place within the bilateral descent group if they achieved a karaengship. The more powerful the patrilineal royalty, the larger its following of attached noble patrilines. In short, securing the patrilineal succession stimulated political expansion, to such a degree that the power of any monarch was closely related to his number of wives.

Royal polygyny also generated a bank of princesses who tended to marry other royal lines and entrench the royalty's genealogical distinctiveness. Yet because these daughters' status was systematically downgraded, they could also marry nobles either attached to some royal patriline or descended from local status lineages. This did not create any dangers for the royal patriline as long as it kept its position of power. The offspring from these marriages were simply not admitted into the royal core.

If the system excluded by patrilineal descent towards the centre, it also included by bilateral descent towards the peripheries. Men from a higher status lineage could attach themselves to a wife from a lower status lineage, and the offspring could then belong to the wife's group. (Hence the indigenous view which derives the nobility from the marriage between commoners and descendants of the Tomanurung.) This privilege allowed the powerful lineages to dump their superfluous proportion of well-born men towards the margins. The men then held exalted positions within their group (witness Daeng Bunding in Kasepekang) which enjoyed greater prestige because of its attachment towards the centre. The privilege also allowed a powerful royal patriline to absorb territorial titles previously belonging to autonomous patrilines. The powerful royal retained his membership within his natal group while his wife, as the princess from the weaker line, transmitted the right of office to her husband through marriage, or to their sons through bilateral descent. (Note that the Konjo 
did not permit men this right of affiliation or membership within two cores [Rössler 1987:65], but the Gowa royalty did not observe this nicety during their territorial expansion.)

In a very practical sense the king was the husband of his realm (cf. Jordaan and de Josselin de Jong 1985). The legitimacy of his control derived from his marriages, or those of his direct ancestors, to princesses within the cores of the subjugated domains. So during 1500-1593 the Gowa royalty attracted status wives from those areas which Gowa came to rule. The territorial ambitions of the Gowa royalty, and its ability to draw status wives, were then contained until the mid-seventeenth century when Gowa legitimately absorbed Sanrabone. With the loss of Gowa's subjugated lands after 1667, Gowa now became "wife" to the two powerful royal lineages in Makassar, Bone-Soppeng and Tallok.

Makassar remained as South Sulawesi's effective capital after the eclipse of the Gowa patriline. The most prestigious title, the rulership of Gowa, was absorbed by Tallok as the most powerful Makassar line. Sirajuddin's ascendancy, which bequeathed a disputed succession until his direct descendants finally monopolized the Gowa rulership late in the nineteenth century (see Patunru 1983:76-99), is not conventionally registered as a dynastic change (e.g. Patunru 1983). In the sense that the disputed succession involved closely related Makassar lineages, and that Tallok's origins are ultimately one with Gowa's (Figure 1), there was indeed no dynastic change. Thus the principle of bilateral membership not only allowed the legitimate passage of authority between peer patrilines, it also tended to ensure continuity of social organization by resisting unrelated factions. Analysis along these lines may help to explain why western Indonesian (and Southeast Asian) political history suggests a multiplicity of "dynasties" centred in comparatively few heartlands and often showing strong cross-dynasty continuity.

\section{Acknowledgments}

Campbell Macknight and Peter Bellwood have unstintingly provided incisive supervision. P.E. de Josselin de Jong, Tony Reid, Jos Platenkamp and Ian Caldwell have assisted me with their comments, contacts, and copies of relevant papers. In particular I thank Jim Fox and Clifford Sather who perceived the potential of my initial analysis and guided it towards a product which (I hope) qualifies as sound anthropology.

\section{References}

Acciaioli, Gregory L.

1989 Searching for good fortune: the making of a Bugis shore community at Lake Lindu, Central Sulawesi. PhD thesis, The Australian National University. 
Andaya, Leonard Y.

1981 The heritage of Arung Palakka. A history of South Sulawesi (Celebes) in the seventeenth century. The Hague: Martinus Nijhoff.

Bulbeck, F. David

1986-87 Survey of open archaeological sites in South Sulawesi 1986-1987. Bulletin of the Indo-Pacific Prehistory Association 7:36-50.

1990 The landscape of the Makassar War. Canberra Anthropology 13(1):78-99.

1992 A tale of two kingdoms. The historical archaeology of Gowa and Tallok, South Sulawesi, Indonesia. PhD thesis, The Australian National University.

Caldwell, Ian A.

1988 South Sulawesi AD 1300-1600: ten Bugis texts. PhD thesis, The Australian National University.

Cense, A.A.

1966 Old Buginese and Macassarese diaries. Bijdragen van het Koninklijk Instituut 122:416-428.

Chabot, Henri T.

1950 Verwantschap, stand en sexe in Zuid-Celebes. Groningen: J.B. Wolters. English translation by R. Neuse (1960) Kinship, status and sex in South Celebes. New Haven: Human Relations Area Files.

Fox, James J.

1971 A Rotinese dynastic genealogy: structure and event. In T.O. Beidelman (ed.) The translation of culture. London: Tavistock.

1995 Austronesian societies and their transformations. In Peter Bellwood, James J. Fox and Darrell Tryon (eds) The Austronesians: historical and comparative perspectives, pp.214-228. Canberra: Research School of Pacific and Asian Studies, The Australian National University.

Friedericy, H.J.

1933 De standen bij de Boegineezen en Makassaren. Bijdragen tot de Taal-, Land- en Volkenkunde van Nederlandsch Indiè 90:447-602.

Grimes, Charles E. and Barbara D. Grimes

1987 Languages of South Sulawesi. Pacific Linguistics Series D No. 78. Canberra: Department of Linguistics, Research School of Pacific Studies, The Australian National University.

Gullick, J.M. 
1958 Indigenous political systems of western Malaya. Revised edition 1988. London: Athlone Press.

Jordaan, R.E. and P.E. de Josselin de Jong

1985 Sickness as a metaphor in Indonesian political myths. Bijdragen tot de Taal-, Land- en Volkenkunde 141:253-274.

Josselin de Jong, P.E. de

1980 Ruler and realm: political myths in western Indonesia. Mededelingen der Koninklijke Nederlandse Akademie van Wetenschappen, afd. Letterkunde n.s. 43(1):3-19.

Kallupa, Bahru

1984 Laporan pengumpulan data peninggalan sejarah dan purbakala di Kabupaten Barru. Ujung Pandang: Suaka Peninggalan Sejarah dan Purbakala Sulawesi Selatan.

Kamaruddin, H.D. Mangemba, P. Parawansa and M. Mappaseleng

1985-86 Lontarak Bilang raja Gowa dan Tallok (naskah Makassar). Ujung Pandang: Proyek Penelitian dan Pengkajian Kebudayaan Sulawesi Selatan LaGaligo.

Millar, S.B.

1989 Bugis weddings. Rituals of social location in modern Indonesia. University of California at Berkeley Monograph Series No. 29. Berkeley: Center for South and Southeast Asian Studies.

Mukhlis

1975 Struktur birokrasi kerajaan Gowa jaman pemerintahan Sultan Hasanuddin (1653-1669). Yogyakarta: Sarjana thesis, Universitas Gadjah Mada.

Noorduyn, J.

1987 Bima en Sumbawa. Bijdragen tot de geschiedenis van de sultanaten Bima en Sumbawa door A. Ligtvoet en G.P. Rouffaer. Dordrecht: Foris Publications.

Palmier, Leslie H.

1969 Social status and power in Java (corrected edition). London: Athlone Press.

Patunru, Abd Razak Daeng

1983 Sejarah Gowa. Ujung Pandang: Yayasan Kebudayaan Sulawesi Selatan di Makassar.

Pelras, Christian 
1977 Les premières données occidentales concernant Célèbes-sud. Bijdragen tot de Taal-, Land-en Volkenkunde 133:227-260.

Rahim, A. and B. Ridwan

1975 Sejarah kerajaan Tallo' (suatu transkripsi lontara'). Ujung Pandang: Kantor Cabang II Lembaga Sejarah dan Antropologi.

Reid, Anthony

1983 The rise of Makassar. Review of Indonesian and Malaysian Affairs 17:117160.

1987 Pluralism and progress in seventeenth century Makassar. Paper presented at the Leiden workshop "Trade, society and belief in South Sulawesi". MS.

1988 Southeast Asia in the age of commerce. Vol. 1: The lands below the winds. New Haven: Yale University Press.

Rössler, Martin

1987 Die soziale Realität des Rituals. Kontinuität und Wandel bei den Makassar von Gowa (Süd-Sulawesi/Indonesien). Berlin: Dietrich Reimer Verlag.

Röttger-Rössler, Birgitt

1989 Rang und Ansehen bei den Makassar von Gowa (Süd-Sulawesi/Indonesien). Berlin: Dietrich Reimer Verlag.

Wolhoff, G.J. and Abdurrahim

n.d.

c.1959 Sedjarah Goa. Makassar (Ujung Pandang): Jajasan Kebudayaan Sulawesi Selatan dan Tenggara. 